\title{
Penerapan Model Pembelajaran Discovery Learning untuk Meningkatkan Aktivitas dan Hasil Belajar Siswa MAN 1 Lombok Timur
}

\author{
Sri Hida Wahyuni \\ Madrasah Aliyah Negeri (MAN) 1 Lombok Timur - Provinsi NTB \\ Corresponding Author Email: srihidawahyuni2@gmail.com
}

\begin{abstract}
This study aims to improve student learning outcomes and activeness through the application of discovery learning models. This research method uses classroom action research which consists of 2 cycles. Each cycle consists of 4 (four) stages, namely planning, implementing, observing and reflecting. The subjects of this study were students of class XII MIA-1 MAN 1 East Lombok. The research instrument used observation sheets, documentation, and tests. The data analysis technique of this research is using descriptive analysis. The results of this study indicate that in the first cycle, the percentage of classical completeness of learning outcomes and the average level of activeness of students was $18 \%$ and $76 \%$, respectively. Whereas in cycle II, the percentage of classical completeness of learning outcomes and the average level of activeness of students was $76 \%$ and $90 \%$, respectively. This proves that, the application of discovery learning learning models can improve the results and learning activeness of class XII MIA-1 MAN 1 East Lombok, especially three dimensional material.
\end{abstract}

\begin{abstract}
Abstrak: Penelitian ini bertujuan untuk meningkatkan hasil belajar dan keaktifan siswa melalui penerapan model pembelajaran discovery learning. Metode penelitian ini menggunakan penelitian tindakan kelas yang terdiri dari 2 siklus. Masing-masing siklus terdiri dari 4 (empat) tahapan yaitu perencanaan, pelaksanaan, observasi dan refleksi. Subyek penelitian ini adalah siswa kelas XII MIA-1 MAN 1 Lombok Timur. Instrumen penelitian ini menggunakan lembar observasi, dokumentasi, dan tes. Teknik analisis data penelitian ini menggunakan analisis deskriptif. Hasil penelitian ini menunjukkan bahwa pada siklus I diperoleh persentase ketuntasan klasikal hasil belajar dan rata-rata tingkat keaktifan peserta didik berturut-turut adalah $18 \%$ dan $76 \%$. Sedangkan pada siklus II, diperoleh persentase ketuntasan klasikal hasil belajar dan ratarata tingkat keaktifan peserta didik berturut-turut adalah $76 \%$ dan $90 \%$. Hal ini membuktikan bahwa, penerapan model pembelajaran discovery learning dapat meningkatkan hasil dan keaktifan belajar peserta didik kelas XII MIA-1 MAN 1 Lombok Timur khususnya materi dimensi tiga.
\end{abstract}

\section{Article History}

Received: 26-02-2021

Revised: 17-03-2021

Published: 14-04-2021

Key Words:

Discovery Learning,

Learning Activities,

Learning Outcomes.

\section{Sejarah Artikel}

Diterima: 26-02-2021

Direvisi: $17-03-2021$

Diterbitkan: 14-04-2021

\section{Kata Kunci:}

Discovery Learning, Aktivitas Belajar, Hasil Belajar.

How to Cite: Wahyuni, S. (2021). Penerapan Model Pembelajaran Discovery Learning untuk Meningkatkan Aktivitas dan Hasil Belajar Siswa MAN 1 Lombok Timur. Jurnal Teknologi Pendidikan : Jurnal Penelitian dan Pengembangan Pembelajaran, 6(1). doi:https://doi.org/10.33394/jtp.v6i1.3720

This is an open-access article under the CC-BY-SA License.

\section{Pendahuluan}

Keaktifan belajar merupakan unsur dasar yang penting bagi keberhasilan proses pembelajaran. Karena itu, proses pembelajaran pada setiap satuan pendidikan dasar dan menengah harus interaktif, inspiratif, menyenangkan, menantang, dan memotivasi peserta didik untuk berpartisipasi aktif serta memberikan ruang yang cukup bagi prakarsa, kreativitas dan kemandirian sesuai dengan bakat, minat, dan perkembangan fisik serta psikologis peserta didik (Permendiknas Nomor 41, 2007). Sementara itu, Trinandita (2008) menyatakan bahwa hal yang paling mendasar yang dituntut dalam proses pembelajaran adalah keaktifan siswa. 
Keaktifan siswa dalam proses pembelajaran akan menyebabkan interaksi yang efektif, baik antara guru dengan siswa maupun antara para siswa. Hal ini akan mengakibatkan suasana kelas menjadi kondusif, di mana masing-masing siswa dapat melibatkan kemampuannya semaksimal mungkin. Aktivitas yang timbul dari siswa akan mengakibatkan pula terbentuknya pengetahuan dan keterampilan yang akan mengarah pada peningkatan prestasi.

Keaktifan siswa dalam pembelajaran meliputi keaktifan untuk bertanya, mengemukakan pendapat, memerhatikan pada waktu pembelajaran. Mulyasa (2002) menjelaskan bahwa pembelajaran dikatakan berhasil dan berkualitas apaapabila seluruhnya atau setidak-tidaknya sebagian besar (75\%) peserta didik terlibat secara aktif, baik fisik, mental maupun sosial dalam proses pembelajaran.

Proses pembelajaran untuk mencapai sebuah tujuan bukanlah perkara mudah terlebih lagi dalam masa pandemi ini. Faktor guru, murid dan lingkungan merupakan faktor utama yang saling berhubungan dan mempengaruhi satu dan lainnya dalam memunculkan persoalan-persoalan dalam kelas, sehingga pembelajaran menjadi kurang efektif dan efesien. Guru yang kurang mampu memilih metode atau model yang sesuai dengan karakteristik mata pelajaran, siswa yang hilang semangat dan motivasinya untuk belajar sampai pada lingkungan yang kurang mendukung, berupa sekolah yang menganjurkan tidak membebani siswa dalam belajar

Merujuk hasil observasi dan refleksi dikelas, model pembelajaran yang diterapkan oleh guru tampaknya kurang mendukung siswa untuk aktif belajar, kurang memfasilitasi siswa dalam proses pengembangan berpikir seperti menemukan konsep sendiri dalam materi pembelajaran, sehingga siswa menjadi pasif dalam belajar di kelas. Kurang aktifnya siswa dalam kelas mempengaruhi hasil penilaian harian, hal ini terbukti dengan banyaknya hasil belajar siswa yang tidak mencapai KKM, Setelah berdiskusi dengan guru matematika kelas XI, diambil kesimpulan bahwa nilai XI MIA-1, yaitu pada materi limit fungsi yang dilaksanakan secara tatap muka, siswa yang memperoleh nilai di atas KKM hanya $23 \%$.

Dalam hal ini diasumsikan bahwa penyebab hasil belajar siswa belum memuaskan dipengaruhi oleh beberapa hal, yaitu: 1) motivasi dan minat belajar siswa kurang, 2) banyak siswa yang tidak aktif mengikuti pembelajaran, 3) dalam diskusi banyak siswa yang pasif dan takut bertanya kepada guru apabila ada hal yang belum dimengerti, 4) keberanian siswa untuk berbicara, baik menjawab maupun menanggapi permasalahan masih kurang, dan 5) ketuntasan klasikal ulangan harian kurang dari $70 \%$.

Kenyataan di atas mendorong guru selaku peneliti, sebagai pelaksana pendidikan yang bertanggung jawab langsung terhadap kemajuan belajar siswa harus pandai-pandai memilih strategi pembelajaran. Pemilihan model pembelajaran yang tepat merupakan manifestasi dari kreatifitas guru agar siswa termotivasi untuk mengikuti aktivitas belajar dengan serius sehingga hasil belajar siswa pun ikut meningkat. Salah satu model pembelajaran yang digunakan dalam penelitian ini yaitu model discovery learning. Model discovery learning merupakan salah satu model pembelajaraan yang menekankan pada pentingnya pemahaman siswa terhadap materi yang dipelajarinya melalui keterlibatan siswa secara aktif dalam proses pembelajaran (Agustian, 2012; Susmiati, 2020; Nurmiati, 2020; Nuryaningsih, 2021; Suarni, 2021). Selanjutnya Bruner dalam Fitriana (2019), Mahartati (2017), Raihun (2019) menjelaskan bahwa discovery learning sesuai dengan pencarian pengetahuan secara aktif oleh siswa, dan dengan sendirinya memberikan hasil yang paling baik. Sehingga, dengan siswa sendiri yang berusaha mencari tahu konsep dari suatu pelajaran, maka siswa akan memahami konsep itu dengan sangat baik. Adapun tujuan penelitian ini adalah untuk 
meningkatkan hasil belajar dan keaktifan siswa melalui penerapan model pembelajaran discovery learning di MAN 1 lombok Timur.

\section{Metode Penelitian}

Penelitian ini merupakan penelitian tindakan kelas. Penelitian Tindakan ini dilaksanakan di MAN 1 Lombok Timur pada semester ganjil tahun pelajaran 2020/2021. Sabyek penelitian adalah siswa kelas XII MIA-1 sebanyak 35 orang. Penelitian ini dilaksanakan dalam dua siklus, dimana siklus I dilaksanakan dalam tiga kali pertemuan begitu juga dengan siklus II tiga kali pertemuan. Setiap siklus tindakan terdiri atas empat Langkah, yaitu perencanaan, pelaksanaan tindakan, observasi, dan evaluasi-refleksi.

Pada tahap perencanaan peneliti membuat instrumen penelitian, seperti RPP pembelajaran discovery, LKS, lembar observasi siswa dan guru dan soal ulangan untuk siklus I dan siklus II. Semua disusun berdasarkan tahapan-tahapan model pembelajaran discovery learning. Evaluasi kegiatan guru dan siswa dilaksanakan selama pembelajaran. Evaluasi pemahaman dilaksanakan pada akhir setiap siklus. Hasil observasi dan evaluasi dianalisis secara deskriptif, kemudian digunakan sebagai bahan refleksi untuk didiskusikan oleh observer dan guru dalam menentukan tindakan perbaikan di siklus selanjutnya. Data aktivitas siswa yang diperoleh dari hasil observasi dianalisis secara deskriptif kuantitatif dengan rumus:

$$
\begin{aligned}
& \bar{X}=\frac{\sum X}{\sum N} \\
& \text { Keterangan } \\
& \bar{X}=\text { Niai rata-rata } \\
& \sum X=\text { Jumlah nilai siswa } \\
& \sum N=\text { Jumlah siswa (Sudijono, 2010) }
\end{aligned}
$$

Adapun kriteria untuk menentukan standar persentase aktivitas siswa dapat dilihat pada tabel di bawah ini.

Tabel 1: Kriteria Aktivita Belajar Siswa

\begin{tabular}{|c|c|}
\hline Aktivitas Belajar & Kriteria \\
\hline $86-100$ & Sangat aktif \\
$71-85$ & Aktif \\
$65-70$ & Cukup aktif \\
$<65$ & Kurang aktif \\
\hline
\end{tabular}

Sedangkan nilai ketuntasan belajar klasikal ini diperoleh dengan rumus sebagai berikut:

$$
\text { Ketuntasan Klasikal }=\frac{\text { jumlah peserta didik tuntas belajar }}{\text { jumlah peserta didik seluruhnya }} \times 100 \%
$$

Adapun indikator keberhasilan dalam penelitian ini adalah apabila $75 \%$ siswa telah mencapai syarat ketuntasan belajar minimal untuk hasil belajar, yaitu 75 dan rata-rata keaktifan peserta didik dalam pembelajaran $\geq 75 \%$ dengan predikat minimal "baik" atau "sangat baik".

\section{Hasil Penelitian dan Pembahasan}

Berdasarkan data hasil penilaian dengan menggunakan tes pada siklus I, dari jumlah peserta didik 35 orang di kelas XII MIA 1, sebanyak 6 orang peserta didik berhasil mencapai $\mathrm{KKM}=75$ yang telah ditetapkan sebelumnya. Sementara 28 orang siswa diantaranya masih belum tuntas dan 1 orang siswa tidak mengikuti pembelajaran maupun ujian karena selama proses penelitian, siswa tersebut dalam keadaan sakit. Jumlah tersebut apabila dituang dalam 
bentuk persentase ketuntasan belajar klasikal, maka diperoleh prosentase sebesar 18\%, sehingga jauh dari ketuntasan yang ditetapkan.

Rendahnya nilai ulangan siklus I dikarenakan pada saat dilaksanakan ujian siklus I, sembilan orang siswa pada hari yang sama akan mengikuti lomba paskibra tingkat provinsi dan lomba ekonomi tingkat nasional yang berakibat tidak fokusnya siswa menjawab soal, dan memaksakan diri untuk mengikuti ujian tanpa persiapan yang cukup. Selain itu juga beberapa siswa tidak masuk pada pertemuan pertama dan pertemuan kedua siklus I. Dari analisis ulangan siswa didapatkan bahwa siswa sebenarnya memahami konsep jarak titik ke garis, tetapi mereka bingung dalam menentukan jarak titik ke titik dimana pembelajaran tersebut dilaksanakan secara daring. Pada pertemuan kedua jarak titik ke bidang, walaupun siswa merasa memahami bagaimana konsep jarak titik ke bidang tapi karna kurangnya disiplin waktu pada tahapan pembelajaran discovery learning siswa belum diberikan latihan yang cukup unuk memahami konsep jarak titik ke bidang sehingga berakibat pada rendahnya nilai ujian siklus I. Hal ini sesuai dengan konsep bahwa salah satu kekurangan discovery learning bahwa discovery learning lebih cocok untuk mengembangkan pemahaman, sedangkan mengembangkan aspek konsep, keterampilan dan emosi secara keseluruhan kurang mendapat perhatian. Sehingga seorang guru harus benar benar disiplin waktu dalam menerapkan sintak discovery learning, sehingga siswa memiliki banyak waktu dalam latihan soal.

Pada siklus I ini rata-rata aktivitas belajar siswa mencapai $71 \%$ dengan katagori "aktif". Hal ini disebabkan siswa sangat antusias karena model pembelajaran ini baru bagi mereka, karena siswa sendiri yang menemukan konsep matematika yang biasanya guru yang menjelaskan konsep terlebih dahulu. Karena hasil belajar siswa masih jauh dari indikator keberhasilan, maka penelitian ini akan dilanjutkan ke siklus II.

Setelah pelaksanaan tindakan pada siklus II, diperoleh nilai dengan persentase ketuntasan belajar klasikal mencapai $76 \%$. Angka ini mengalami peningkatan dari persentase ketuntasan belajar klasikal pada siklus I. Dari 34 peserta didik, 26 orang diantaranya berhasil memperoleh nilai ulangan harian di atas 75 dan 8 orang peserta didik belum mencapai nilai ketuntasan yang sudah ditetapkan.Hhal ini dikarenakan pada pada pertemuan kedua siklus II ada 7 orang siswa tidak masuk sekolah karena terkendala hujan yang sangat deras, yang berakibat kurang pahamnya siswa pada materi sudut antara garis dan bidang. Pada siklus II rata-rata aktivitas belajar siswa belajar klasikal pada siklus II mencapai 90\%. Angka ini apabila dikonversi, maka mencapai predikat "sangat baik".

Keberhasilan peneliti mencapai target pembelajaran yang diinginkan tidak terlepas dari evaluasi yang dilakukan mengenai kinerja guru pada siklus I. Pada siklus II, peneliti telah menerapkan model pembelajaran discovery learning sesuai sintak yang ada dan disiplin terhadap waktu yang telah direncanakan sehingga diperoleh hasil belajar maupun keaktifan belajar peserta didik seperti yang diinginkan. Untuk melihat signifikansi hasil penelitian tahap demi tahap, peneliti sajikan dalam tabel berikut.

Tabel 2: Signifikansi Perkembangan Hasil Penelitian

\begin{tabular}{|c|c|c|}
\hline Tahapan Penelitian & Keaktifan Beajar & Hasil Belajar \\
\hline Capaian Siklus I & $71 \%$ & $18 \%$ \\
\hline Capaian Siklus II & $90 \%$ & $76 \%$ \\
\hline
\end{tabular}

Apabila aktivitas dan hasil belajar siswa divisualkan dalam bentuk grafik, maka akan tampak seperti di bawah ini 


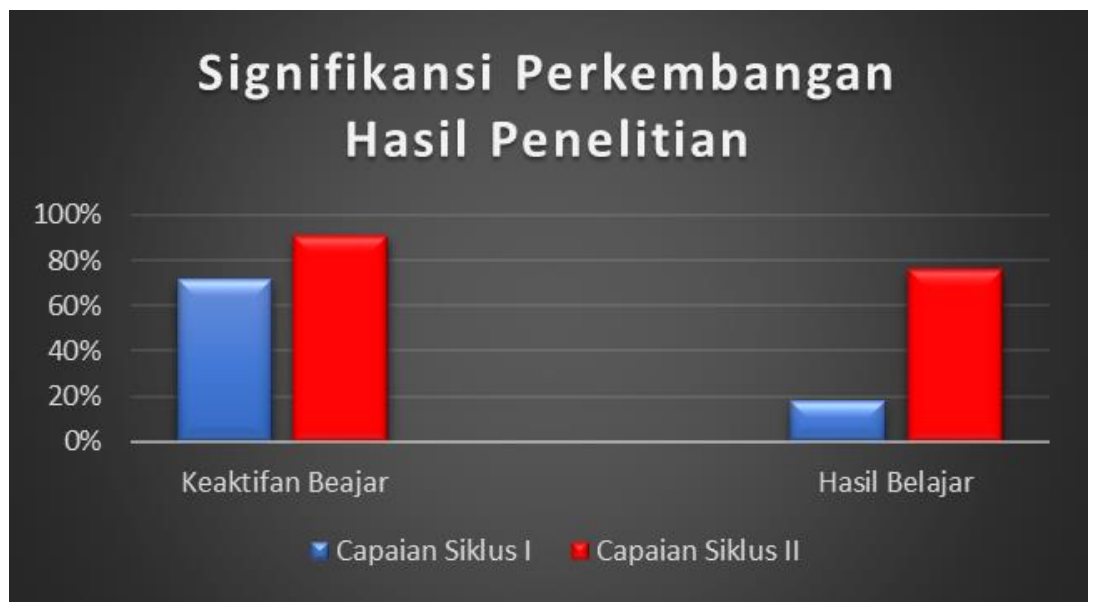

Gambar 1. Grafik Signifikansi Perkembangan Hasil Penelitian

Grafik di atas memperlihatkan kemajuan yang cukup signifikan dari siklus I sampai dengan siklus II, baik hasil belajar dengan ketuntasan klasikal mencapai 76\% maupun keaktifan peserta didik dengan rata-rata $90 \%$ atau mendapat predikat "sangat baik". Akhirnya dapat disimpulan bahwa model pembelajaran discovery learning dapat diterapkan pada pembelajaran matematika wajib khususnya materi dimensi tiga di kelas XII MIA-1 MAN 1 Lombok Timur, karena mampu meningkatkan aktivitas dan hasil belajar siswa.

\section{Kesimpulan}

Berdasarkan deskripsi hasil penelitian, maka dapat disimpulkan bahwa penerapan model pembelajaran discovery learning dapat meningkatkan aktivitas belajar dan hasil belajar peserta didik pada materi dimensi tiga di kelas XII MIA-1 MAN 1 Lombok Timur tahun pelajaran 2020/2021. Hal ini terbuki pada siklus I diperoleh persentase ketuntasan klasikal hasil belajar dan rata-rata tingkat keaktifan peserta didik berturut-turut adalah $18 \%$ dan $76 \%$, meningkat pada siklus II dengan persentase ketuntasan klasikal hasil belajar dan rata-rata tingkat keaktifan peserta didik berturut-turut adalah 76\% dan 90\% (predikat "sangat baik”).

\section{Saran}

Saran yang dapat disampaikan bagi guru matematika lainnya adalah untuk menerapkan model pembelajaran ini karena hasil penelitian menunjukkan siswa lebih aktif dalam mengikuti proses pembelajaran, sehingga berdampak meningkatkan hasil belajar siswa.

\section{Daftar Pustaka}

Amir, Taufiq. (2009). Inovasi Pendidikan melalui Discovery Learning. Jakarta: Kencana Prenada Media Group.

Arikunto, Suharsimi, dkk. (2008). Penelitian Tindakan Kelas. Jakarta: Bumi Aksara

Balai Diklat Keagamaan Denpasar. (2019). Model Pembelajaran Discovery dan Inquiry Learning, Bahan Ajar Berbasis e-Learning

Fitriana, F. (2019). Penerapan Model Discovery Learning pada Pembelajaran IPA Materi Tekanan untuk Meningkatkan Hasil Belajar Siswa. Jurnal Kependidikan: Jurnal Hasil Penelitian dan Kajian Kepustakaan di Bidang Pendidikan, Pengajaran dan Pembelajaran, 5(2), 100-108. doi:https://doi.org/10.33394/jk.v5i2.1805

Hamalik, Hamalik. (2007). Kurikulum dan Pembelajaran, Jakarta: PT. Bumi Aksara,. 
Mahartati, I. (2017). Meningkatkan Motivasi dan Hasil Belajar Tematik Peserta Didik dengan Mengoptimalkan Penerapan Model Discovery Learning di SD Negeri 3 Cakranegara. Jurnal Kependidikan: Jurnal Hasil Penelitian dan Kajian Kepustakaan di Bidang Pendidikan, Pengajaran dan Pembelajaran, 3(2). doi:https://doi.org/10.33394/jk.v3i2.568

Nurmiati, B. (2020). Meningkatkan Motivasi dan Hasil Belajar Peserta Didik dengan Mengoptimalkan Penerapan Model Discovery Learning di SD Negeri 2 Cakranegara. Jurnal Paedagogy, 6(1), 1-7. doi:https://doi.org/10.33394/jp.v6i1.2523

Nuryaningsih, W. (2021). Penerapan Model Discovery Learning Berkolaborasi Google Classroom dan WhatsApp Group untuk Meningkatkan Kompetensi Siswa dalam Menulis Teks Eksplanasi. Jurnal Paedagogy, $\quad 8(2), \quad$ 159-168. doi:https://doi.org/10.33394/jp.v8i2.3540

Permendiknas RI No 41 Tahun 2007 tentang Standar Proses, Jakarta: BSNP

Raihun, R. (2019). Penerapan Model Pembelajaran Discovery Learning untuk Meningkatkan Prestasi Belajar PPKn Peserta Didik Kelas IX.3 SMP Negeri 4 Praya Timur. Jurnal Kependidikan: Jurnal Hasil Penelitian dan Kajian Kepustakaan di Bidang Pendidikan, Pengajaran dan Pembelajaran, 5(2), 124-132. doi:https://doi.org/10.33394/jk.v5i2.1809

Rusman. (2013). Belajar dan Pembelajaran Berbasis Komputer, Jakarta: Alfabet.

Sanjaya, Wina. (2014). Strategi Pembelajaran Berorientasi Standar Proses Pendidikan. Jakarta: Kencana

Sardiman, AM. (2011). Interaksi dan Motivasi Belajar Mengajar, Jakarta: Rajawali Pers

Sirait, Marulin. (2017). Model Pembelajaran Berbasis Discovery-Inkuiri dan Kontribusinya terhadap Penguatan Kualitas Pembelajaran di Sekolah Dasar. Jurnal Pendidikan $\begin{array}{llll}\text { dasar } & \text { Vol.1 } & \text { Nomor } & \text { 2.STAIN }\end{array}$ http://journal.staincurup.ac.id/index.php/arriayah

Suarni, G., Rizka, M., \& Zinnurain, Z. (2021). Analisis Pengaruh Penerapan Model Pembelajaran Sains Teknologi Masyarakat Terhadap Hasil Belajar Siswa. Jurnal Paedagogy, 8(1), 31-38. doi:https://doi.org/10.33394/jp.v8i1.3226

Susmiati, E. (2020). Meningkatkan Motivasi Belajar Bahasa Indonesia Melalui Penerapan Model Discovery Learning dan Media Video Dalam Kondisi Pandemi Covid-19 bagi Siswa SMPN 2 Gangga. Jurnal Paedagogy, 7(3), 210-215. doi:https://doi.org/10.33394/jp.v7i3.2732

Trinandita. $2008 . \quad$ Keaktifan Siswa. (http://ipotes.wordpress.com/2008/05/24/prestasi-belajar/, diakses 23 Agustus 2019).

Tompo, B., Ahmad, M.A.,\& Muris. (2016). Pengembangan Model Pembelajran DiscoveryInquiry untuk Mereduksi Miskonsepsi IPA Peserta Didik SMP. Jurnal Sains dan Pendidikan Fisika Jilid 12 Nomor 3 hal. 240-253 